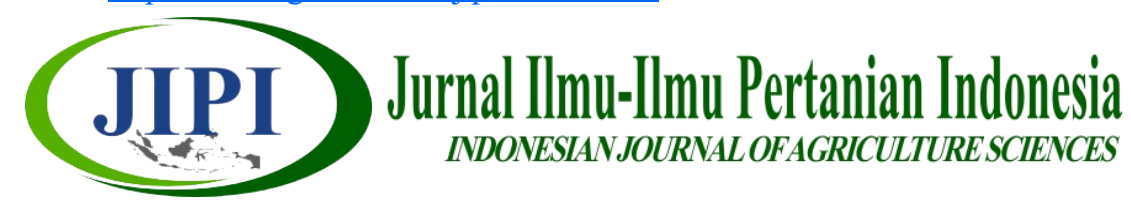

\title{
EFISIENSI PEMANFAATAN LAHAN PADA SISTEM TUMPANGSARI DENGAN BERBAGAI JARAK TANAM JAGUNG DAN VARIETAS KACANG HIJAU
}

\author{
Desi Lestari ${ }^{1}$, Edhi Turmudi $^{1^{*}}$, Dotti Suryati ${ }^{1}$ \\ ${ }^{1}$ Program Studi Agroekoteknologi, Fakultas Pertanian Universitas Bengkulu \\ * Corresponding Author : edhiturmudi@unib.ac.id
}

\begin{abstract}
[EFFICIENCY OF LAND USE IN MULTIPLE CROPPING SYSTEM WITH VARIOUS CORN PLANT AND MUNG BEAN VARIETIES]. This study aims to find out the precise planting distance of corn with mung bean varieties that are suitable for increasing the efficiency of land use in terms of ecology and agronomy. Research has been carried out in the agricultural land in September 2018-January 2019 using a split-plot design. The main plot of planting spacing of corn which is $60 \mathrm{~cm} \times 30 \mathrm{~cm}, 90 \mathrm{~cm} \times 30 \mathrm{~cm}$, and $120 \mathrm{~cm} \times 30 \mathrm{~cm}$, subplots ie mung bean varieties (Kutilang, Vima-1, Vima-2, Vima-3). As a comparison of intercropping systems, monocultures are cultivated by corn and mung beans. The results showed that in general intercropping of maize and mung bean NKL $>1$, ecologically and agronomically efficient. However, this efficient level can be distinguished based on the spacing of corn and mung bean varieties. The best ecological efficiency at $120 \mathrm{~cm}$ x $30 \mathrm{~cm}$ corn spacing, while the best agronomic efficiency in Virna -3 mung bean varieties.
\end{abstract}

Keyword: corn, multiple cropping, mung bean, planting distance, varieties

\begin{abstract}
ABSTRAK
Upaya peningkatan produktifitas lahan pertanian di daerah berpenduduk padat penting dilakukan untuk mencukupi kebutuhan pangan. Sistem tumpangsari dapat diterapkan karena menghasilkan lebih dari satu jenis produk tanaman pada sebidang lahan dalam waktu yang bersamaan, secara produktif dan efisien. Penelitian ini bertujuan untuk mendapatkan jarak tanam jagung yang tepat dengan varietas kacang hijau yang cocok untuk meningkatkan efisiensi pemanfaatan lahan dari sisi ekologi dan agronomi. Penelitian telah dilaksanakan di lahan pertanian pada bulan September 2018-Januari 2019 menggunakan rancangan petak terbagi atau split plot. Perlakuan jarak tanam jagung yaitu $60 \mathrm{~cm}$ x $30 \mathrm{~cm}, 90 \mathrm{~cm}$ x $30 \mathrm{~cm}$, dan $120 \mathrm{~cm}$ x $30 \mathrm{~cm}$, ditempatkan sebagai petak utama. Varietas kacang hijau (Kutilang, Vima-1, Vima-2, Vima-3) ditempatkan sebagai anak petak. Penanaman jagung dan kacang hijau secara monokultur digunakan sebagai pembanding pertanaman sistem tumpangsari. Hasil penelitian menunjukkan bahwa secara umum tumpangsari jagung dan kacang hijau memiliki NKL $>1$, yang berarti efisien secara ekologi dan agronomi. Namun, tingkat efisien tersebut dapat dibedakan berdasarkan jarak tanam jagung dan varietas kacang hijau. Efisiensi secara ekologi tertinggi pada jarak tanam jagung $120 \mathrm{~cm}$ x $30 \mathrm{~cm}$, sedangkan efisiensi secara agronomi yang tertinggi pada varietas kacang hijau Vima-3.
\end{abstract}

Kata kunci: jagung, jarak tanam, kacang hijau, monokultur, tumpangsari, varietas 


\section{PENDAHULUAN}

Indonesia merupakan negara agraris, sektor pertanian menjadi andalan utama dalam pembangunan ekonomi. Sebagian besar penduduknya bermata pencaharian di sektor pertanian yang menjadi penyedia bahan pangan bagi masyarakat. Di beberapa daerah yang penduduknya padat seperti di Pulau Jawa umumnya pertaniannya sudah maju, akan tetapi status kepemilikan lahannya sangat sempit yaitu kurang dari 1 ha. Sempitnya lahan menyebabkan penerapan teknologi modern untuk meningkatan produksi pertanian menjadi sulit. Sedangkan hasil pertanian semakin banyak dibutuhkan oleh masyarakat (Manyamsari \& Mujiburrahmad, 2014). Permasalahan yang lain di sektor pertanian adalah banyak lahan pertanian yang dialihfungsikan menjadi lahan non pertanian (Kamilah \& Yulianah, 2016).

Status kepemilikan lahan pertanian di Indonesia relatif sempit, mendorong petani untuk melakukan intensifikasi dalam meningkatkan produktivitas lahan. Telah diketahui dampak negatif intensifikasi adalah terjadi kerusakan lingkungan dan pemerosotan sumber daya alam yang akan mengancam terhadap sistem produksi pertanian (Dewanto et al., 2013). Alternatif yang mungkin dilakukan untuk mengatasi masalah tersebut adalah peningkatan produktivitas lahan dengan diversifikasi tanaman yaitu menanam lebih dari satu jenis tanaman pada sebidang lahan dengan bersamaan atau bergantian. Sistem ini lebih dikenal istilah multiple cropping atau pola pertanaman ganda (Damanhuri et al., 2017). Pola tanam ganda memiliki kelebihan, yaitu dapat memperkecil resiko kegagalan panen, akibat serangan hama ataupun gangguan iklim dalam pemanfaatan lahan untuk pengembangan tanaman pangan. Kelemahan yang ada pada multiple cropping yaitu terjadi persaingan antar tanaman, sehingga dapat menurunkan produktifitas tanaman (Karima et al., 2013).

Sebagian besar wilayah di Indonesia memiliki iklim tropis yang sangat mendukung terjadinya keanekaragaman hayati (Primiani \& Pujiati, 2017). Kondisi ini sangat cocok untuk pengembangan sistem diversifikasi tanaman. Dengan melakukan diversifikasi tanaman dapat memberikan keuntungan baik secara ekonomi maupun lingkungan. Multiple cropping yang biasanya digunakan oleh petani yaitu sistem tumpangsari (Damanhuri et al., 2017).

Tumpangsari merupakan sistem pertanaman yang membudidayakan lebih dari satu jenis tanaman yang ditanam pada waktu bersamaan (Putra et al., 2017). Sistem tumpangsari jagung manis dan kedelai dapat memberikan beberapa keuntungan yaitu efisiensi penggunaan lahan, mengurangi OPT, menambah kesuburan tanah terutama unsur $\mathrm{N}$, dan mendapatkan hasil tanaman beragam (Aisyah \& Herlina, 2018). Sistem tumpangsari juga dapat menekan laju pertumbuhan gulma, dan menghemat pemakaian sarana produksi (Lingga et al., 2015).
Efisiensi merupakan suatu upaya penggunaan sumberdaya secara minimum tetapi dapat memberikan hasil yang tinggi untuk produksi tanaman (Aminah et al., 2014). Selain itu melalui penanaman tumpangsari terdapat tanaman sela yang berfungsi sebagai covercrop sehingga dapat memperkecil evaporasi dan erosi. Efisiensi pemanfaatan lahan tumpangsari dibandingkan dengan monokultur dapat dilihat dari nilai NKL yang dihasilkan tumpangsari tanaman sorgum dengan tanaman kacang tanah, kacang hijau, kacang tunggak dan kacang kedelai lebih dari satu $(>1)$ artinya memberikan hasil yang menguntungkan (Dewi et al., 2017).

Untuk mencapai tujuan efisiensi lahan maka perlu pemilihan jenis tanaman yang tepat yaitu yang memiliki hubungan sinergi atau saling menguntungkan (Wahyuni et al., 2017). Jenis tanaman tersebut harus memiliki karakter hidup yang sama, bisa ditanam di waktu yang bersamaan dan ditempat yang sama, tetapi tidak menimbulkan persaingan yang dapat menurunkan hasil tanaman seperti antara tanaman jagung dan kacang hijau (Catharina, 2009).

Tanaman jagung dan kacang hijau dipercaya mampu membentuk hubungan yang saling menguntungkan. Hubungan simbiosis mutualisme tersebut dikarenakan kacang hijau memiliki kemampuan dalam memfiksasi $\mathrm{N}$ (nitrogen) dari udara bebas yang dibutuhkan bagi tanaman jagung, sebaliknya jagung dapat memberikan naungan terhadap tanaman kacang hijau yang toleran akan cahaya (Sabaruddin et al., 2011).

Jagung adalah tanaman yang tergolong tanaman $\mathrm{C} 4$ yang memiliki sifat laju fotosintesis lebih tinggi dibandingkan tanaman $\mathrm{C} 3$, bertajuk tinggi, efisien dalam penggunaan air, fotorespirasi dan transpirasi rendah, dan mampu beradaptasi dengan baik pada faktor pembatas pertumbuhan dan produksi. Kacang hijau tergolong C3 yang bertajuk rendah, fotosintesis berlangsung pada intesitas cahaya dan suhu relatif lebih rendah sehingga tahan terhadap naungan (Lingga et al., 2015).

Sistem tumpangsari antara tanaman jagung dan bawang prei dengan jarak tanam $60 \mathrm{~cm}$ x $50 \mathrm{~cm}$ dapat meningkatkan efisiensi (Putra et al., 2017). Pengaturan jarak tanam tanaman jagung ini menjadi faktor yang penting dalam upaya untuk meningkatkan produksi tanaman (Utomo et al., 2017). Jarak tanam tanaman jagung yang terlalu jauh akan memaksimalkan dalam penyerapan unsur hara maupun cahaya.

Jarak tanam yang terlalu rapat akan mengakibatkan terjadinya persaingan antar tanaman dalam mendapatkan unsur hara, sinar matahari, dan air sehingga dapat memacu tanaman untuk tumbuh dan memungkinkan pertumbuhan dan perkembangan tanaman menjadi maksimal (Utomo et al., 2017). Tingkat kerapatan tanaman berhubungan dengan populasi tanaman dan sangat menentukan produksi.

Kepadatan populasi tanaman semakin tinggi dapat meningkatkan produksi tanaman. Akan tetapi pertambahan 
populasi tanaman yang melampuai daya dukung lahan akan menurunkan produksi karena adanya kompetisi yang semakin kuat antar tanaman (Aisyah \& Herlina, 2018 ; Tumudi, 2002). Tingkat kompetisi antar jenis tanaman juga dipengaruhi oleh karakter varietas tanaman.

Pemilihan varietas juga menjadi faktor yang penting karena potensi genetik akan menentukan hasil yang cukup tinggi. Pengelolaan kondisi di lingkungan dengan faktor genetik dapat mempengaruhi produksi. Potensi hasil yang tinggi dari varietas tidak akan tercapai, bila pengelolaan lingkungannya tidak dilakukan dengan baik (Sinaga et al., 2017).

Secara garis besar yang membedakan dari setiap varietas yaitu tinggi tanaman, bobot 100 biji, umur panen, dan rata-rata hasil. Kacang hijau varietas Kutilang memiliki tinggi tanaman 53-60 cm, bobot 100 biji sebesar 6,0-7,0 g, waktu panen 60-67 hari, dan ratarata hasil 1,3 ton/ha. Varietas Vima-1 memiliki tinggi tanaman $53 \mathrm{~cm}$, bobot 100 biji $6,3 \mathrm{~g}$, umur panen 57 hari, dan rata-rata hasil 1,38 ton/ha. Varietas Vima-2 memiliki tinggi tanaman $\pm 64,3 \mathrm{~cm}$, bobot 100 biji $6,6 \mathrm{~g}$, umur panen 56 hari, dan rata-rata hasil $\pm 1,8$ ton/ha. Varietas Vima-3 memiliki tinggi tanaman $\pm 75,3 \mathrm{~cm}$, bobot 100 biji $5,9 \mathrm{~g}$, umur panen 60 hari, dan rata-rata hasil 1,8 ton/ha (Balai Penelitian Tanaman Aneka Kacang \& Umbi, 2016).

Jarak tanam jagung dan varietas kacang hijau dapat digunakan sebagai suatu upaya untuk meningkatkan efisiensi pemanfaatan lahan pada tanaman jagung dan kacang hijau. Penelitian tentang pengaturan jarak tanam jagung dan pemilihan varietas kacang hijau untuk meningkatkan efisiensi lahan pada tumpangsari, relatif masih sedikit. Oleh karena itu perlu dilakukan penelitian tentang jarak tanam jagung dengan berbagai varietas kacang hijau, sehingga perlu ditemukan jarak tanam jagung dan varietas kacang hijau yang tepat untuk meningkatkan efisiensi pemanfaatan lahan pada sistem tumpangsari.

Tujuan penelitian ini adalah untuk mendapatkan jarak tanam jagung yang tepat dengan varietas kacang hijau yang cocok untuk meningkatkan efisiensi pemanfaatan lahan dari sisi ekologi dan agronomi.

\section{METODE PENELITIAN}

Penelitian ini dilaksanakan mulai bulan September 2018 sampai Januari 2019, bertempat di lahan pertanian yang memiliki ketinggian $22 \mathrm{~m}$ dpl dengan jenis tanah Ultisol. Percobaan lapangan dengan Rancangan Petak Terbagi yang terdiri atas tiga jarak tanam jagung yaitu $(60 \mathrm{~cm}$ x $30 \mathrm{~cm}, 90 \mathrm{~cm}$ x $30 \mathrm{~cm}$, dan $120 \mathrm{~cm}$ x $30 \mathrm{~cm}$ ) sebagai petak utama dan empat varietas kacang hijau yaitu Kutilang, Vima-1, Vima-2, dan Vima-3 sebagai anak petak yang diulang sebanyak tiga kali. Sebagai pembanding terhadap tanaman tumpangsari, maka ditanam secara monokultur jagung sebanyak 3 petak dan kacang hijau sebanyak 4 petak yang diulang tiga kali, maka jumlah petakan 21 petak.
Lahan yang digunakan dibebaskan dari gulma menggunakan sabit. Pengolahan tanah dilakukan dengan menggunakan traktor dan cangkul hingga tanah menjadi gembur, rata dan bersih dari sisa-sisa perakaran gulma. Lahan dibagi menjadi 3 blok berdasarkan kemiringan. Setiap blok dibagi menjadi 3 petak utama dengan ukuran $12 \mathrm{~m}$ x 3,6 m dan jarak antar petak utama $1 \mathrm{~m}$. Setiap petak utama dibagi menjadi 4 anak petak dengan ukuran $3 \mathrm{~m}$ x 3,6 m. Petakan monokultur dibuat dengan ukuran $3 \mathrm{~m}$ x 3,6 $\mathrm{m}$.

Benih jagung dan kacang hijau yang digunakan adalah benih bersertifikat yang berasal dari Balitkabi Malang, dengan kriteria normal, sehat, dan utuh. Penanaman jagung pada sistem tumpangsari sesuai dengan perlakuan. Penanaman kacang hijau dilakukan sesuai jarak tanam yaitu $30 \mathrm{~cm} \times 30 \mathrm{~cm}$, dan pada sistem tumpangsari, tanaman kacang hijau ditanam diantara barisan tanaman jagung. Lubang tanam dibuat dengan tugal sedalam $3 \mathrm{~cm}$. Benih jagung dan kacang hijau terlebih dahulu direndam kedalam air hangat selama 30 menit sebelum ditanam. Penanam dilakukan dengan cara memasukkan 2 benih pada sistem tumpangsari, dan 3 benih pada sistem monokultur pada setiap lubang tanam. Ke dalam lubang tanam juga diberikan Karbofuran $3 \%$ sebanyak 10 butir. Cara penanaman monokultur jagung maupun kacang hijau sesuai perlakuan jarak tanam.

Pemupukan dengan Urea pada monokultur jagung dilakukan dua kali dengan dosis total $300 \mathrm{~kg} /$ ha atau setara $324 \mathrm{~g} /$ petak. Pemupukan pertama diberikan pada umur 1 minggu setelah tanam (mst) dengan $1 / 2$ dosis total setara $162 \mathrm{~g} /$ petak dan pemupukan kedua diberikan pada umur 5 mst dengan dosis $1 / 2$ dosis total setara $162 \mathrm{~g} /$ petak. Pemupukan TSP dengan dosis total $350 \mathrm{~kg} / \mathrm{ha}$ atau setara $378 \mathrm{~g} /$ petak dan $\mathrm{KCl}$ dengan dosis total $100 \mathrm{~kg} / \mathrm{ha}$ atau setara $108 \mathrm{~g} /$ petak diberikan satu kali pada umur 1 mst.

Pemupukan Urea pada monokultur kacang hijau dilakukan dua kali dengan dosis total $50 \mathrm{~kg} / \mathrm{ha}$ setara $54 \mathrm{~g} /$ petak. Pemupukan pertama diaplikasikan pada umur 1 mst dengan $1 / 2$ dosis total setara $27 \mathrm{~g} /$ petak dan pemupukan kedua diberikan pada umur 5 mst dengan $1 / 2$ dosis total setara $27 \mathrm{~g} /$ petak. Pemupukan TSP dengan dosis total $100 \mathrm{~kg} /$ ha setara $108 \mathrm{~g} /$ petak dan $\mathrm{KCl}$ dengan dosis total $50 \mathrm{~kg} /$ ha setara $54 \mathrm{~g} /$ petak diberikan satu kali pada umur 1 mst.

Pemupukan Urea pada tumpangsari dilakukan dua kali dengan dosis total $175 \mathrm{~kg} /$ ha setara $189 \mathrm{~g} /$ petak. Pemupukan pertama dilakukan saat 1 mst dengan $1 / 2$ dosis total setara 94,5 g/petak dan pemupukan kedua diberikan saat umur 5 mst dengan $1 / 2$ dosis total setara $94,5 \mathrm{~g} /$ petak. Pemupukan TSP dengan dosis total $225 \mathrm{~kg} / \mathrm{ha}$ setara $243 \mathrm{~g} /$ petak dan $\mathrm{KCl}$ dengan dosis total $75 \mathrm{~kg} / \mathrm{ha}$ sebanyak $81 \mathrm{~g} /$ petak diberikan satu kali pada umur 1 mst. Pemupukan dilakukan dengan cara dibuat alur pada petakan, kemudian pupuk ditebar dan selanjutnya ditutup dengan tanah (Purnama et al., 2013). 
Pengairan dilakukan 2 kali sehari ketika tidak turun hujan yaitu pagi dan sore hari dengan cara penyiraman menggunakan gembor. Pengendalian gulma dilakukan pada umur 3 mst dan 9 mst secara manual dengan cara dicabut atau dicangkul. Penyulaman dilakukan setelah tanaman berumur $1 \mathrm{mst}$. Penjarangan tanaman pada sistem tumpangsari dilakukan pada lubang tanam yang tumbuh lebih dari satu tanaman. Sedangkan pada sistem monokultur yang tumbuh lebih dari dua tanaman Pembumbunan dilakukan dengan cara tanah digemburkan dengan menggunakan cangkul kemudian diangkat dan ditimbunkan di sekeliling pangkal batang tanaman. Pengendalian penyakit pada tanaman kacang hijau dilakukan secara kimiawi dengan menggunakan pestisida sintetik yang berbahan aktif mankozeb dengan dosis $3 \mathrm{~g} / \mathrm{L}$ dan diaplikasikan pada umur 56 hari setelah tanam (hst).

Panen jagung dilakukan ketika tanaman sudah menunjukkan kriteria panen dengan ciri-ciri : penampakan lapisan hitam antara tongkol dan biji, serta menguning batang, daun, kelobot serta rambut mengering (Sari et al., 2018). Umur tanaman jagung tidak dapat dijadikan tolak ukur dilakukannya pemanenan tergantung kecepatan pertumbuhan dan varietas tanaman jagung itu sendiri, namun secara umum pemanenan dilakukan pda umur 105 hst. Kriteria panen pada semua varietas kacang hijau dengan ciri-ciri: kulit polong keras atau mengering, bagian polong berwarna coklat atau menghitam dan sebagian besar polong mudah pecah (Rosmaiti, 2018).

Pengamatan variabel utama untuk tanaman kacang hijau terdiri atas luas daun $\left(\mathrm{cm}^{2} /\right.$ helai) mengikuti metode yang dikembangkan Irwan \& Wicaksono (2017); bobot kering berangkasan (g/tanaman); dan bobot biji/petak (g/petak). Untuk tanaman jagung variabel yang diukur ialah luas daun $\left(\mathrm{cm}^{2} /\right.$ helai) yang dilakukan saat tanaman berusia 42 hst mengikuti metode yang dikembangkan Susilo (2015); bobot kering berangkasan (g/tanaman); dan bobot pipilan kering/petak (g/petak). Selain variabel utama, juga diukur beberapa variabel pendukung seperti jumlah polong/tanaman kacang hijau; bobot biji kering/tanaman kacang hijau (g); bobot 100 biji kacang hijau (g); jumlah biji/ baris tanaman jagung; bobot pipilan kering/tanaman jagung (g); bobot 100 pipilan/tanaman jagung (g); kelembaban udara (\%); suhu udara $\left({ }^{0} \mathrm{C}\right)$; dan curah hujan dari Stasiun Klimatologi Kelas 1 Pulau Baai Kota Bengkulu.

Indeks Luas Daun Tumpangsari (ILDT) ditentukan dengan cara menjumlahkan indeks luas daun jagung dan indeks luas daun kacang hijau. Perhitungan luas daun tanaman jagung dilakukan dengan menggunakan rumus panjang $\mathrm{x}$ lebar $\mathrm{x} 0,75 \mathrm{x}$ jumlah daun, luas daun tanaman kacang hijau dengan rumus panjang $x$ lebar $\mathrm{x} 0,54 \times$ jumlah daun. Hasil pengukuran luas daun tersebut digunakan untuk menghitung ILDT dengan rumus :

$$
\text { ILDT = ILD jagung + ILD kacang hijau }
$$

Nisbah Kesetaraan Lahan (NKL) Bobot Berangkasan ditentukan atas dasar persamaan :

$\mathrm{NKL}=\frac{Y a b}{Y a a}+\frac{Y b a}{Y b b} \quad$ atau NKL $=\mathrm{RBB}$ jagung $+\mathrm{RBB}$ kacang hijau

Keterangan :

RBB jagung = relatif bobot berangkasan jagung $\left(\frac{Y a b}{Y a a}\right)$

RBB kacang hijau = relatif bobot berangkasan kacang hijau $\left(\frac{Y b a}{Y b b}\right)$

$\mathrm{Yab}=$ berangkasan tanaman jagung yang ditumpangsarikan;

Yaa $=$ berangkasan tanaman jagung yang monokultur;

Yba $=$ berangkasan tanaman kacang hijau yang ditumpangsarikan;

$\mathrm{Ybb}=$ berangkasan tanaman kacang hijau yang monokultur

NKL Bobot Biji ditentukan atas dasar persamaan berikut :

$\mathrm{NKL}=\frac{Y a b}{Y a a}+\frac{Y b a}{Y b b}$ atau $\mathrm{NKL}=\mathrm{RP}$ jagung $+\mathrm{RB}$ kacang hijau

Keterangan :

RP jagung = relatif pipilan jagung $\left(\frac{Y a b}{Y a a}\right)$

RB kacang hijau = relatif biji kacang hijau $\left(\frac{Y b a}{Y b b}\right)$

$\mathrm{Yab}=$ hasil tanaman jagung yang ditumpangsarikan;

Yaa = hasil tanaman jagung yang monokultur;

$\mathrm{Yba}=$ hasil tanaman kacang hijau yang ditumpangsarikan;

$\mathrm{Ybb}=$ hasil tanaman kacang hijau yang monokultur (Aminah et al.2014).

Data yang dikumpukan diuji secara statistik dengan uji $\mathrm{F}$ pada taraf $5 \%$ dan jika terdapat beda nyata maka dilanjutkan dengan Duncan Multiple Range Test (DMRT) taraf 5\% (Gomez \& Gomez, 1984).

\section{HASIL DAN PEMBAHASAN}

Hasil penelitian sistem tumpangsari varietas kacang hijau dengan jarak tanam jagung, menunjukkan tidak terdapat interaksi nyata antara varietas kacang hijau dengan jarak tanam jagung pada variabel indeks luas daun tumpangsari (ILDT), nisbah kesetaraan lahan (NKL) bobot berangkasan, dan nisbah kesetaraan lahan (NKL) bobot biji berdasarkan uji F pada taraf 5\%. Varietas kacang hijau sebagai faktor tunggal berpengaruh nyata hanya pada NKL bobot biji. Sedangkan perlakuan jarak tanam jagung berpengaruh nyata pada variabel indeks luas daun tumpangsari (ILDT) dan nisbah kesetaraan lahan (NKL) bobot berangkasan (Tabel 1).

Hal tersebut menunjukkan bahwa perlakuan jarak tanam jagung dan varietas kacang hijau tidak saling mempengaruhi terhadap variabel indeks luas daun tumpangsari (ILDT), nisbah kesetaraan lahan (NKL) bobot berangkasan, dan nisbah kesetaraan lahan (NKL) bobot biji. Jarak tanam jagung yang tepat untuk setiap perlakuan varietas kacang hijau tidak bisa ditentukan untuk mendapatkan ILD tumpangsari, NKL bobot berangkasan, 
Tabel 1. Nilai F-hitung ILDT, NKL bobot berangkasan, dan NKL bobot biji

\begin{tabular}{|c|c|c|c|c|}
\hline \multirow{2}{*}{ No. } & \multirow{2}{*}{ Peubah } & \multicolumn{3}{|c|}{ F-Hitung } \\
\hline & & Jarak tanam & Varietas & Interaksi \\
\hline 1. & ILDT & $7,60^{*}$ & $0,02^{\mathrm{ns}}$ & $0,12^{\mathrm{ns}}$ \\
\hline 2. & NKL bobot berangkasan & $12,39^{*}$ & $1,33^{\mathrm{ns}}$ & $0,33^{\mathrm{ns}}$ \\
\hline 3. & NKL bobot biji & $1,78^{\mathrm{ns}}$ & $5,08^{*}$ & $0,34^{\mathrm{ns}}$ \\
\hline & F-Tabel & 6,94 & 3,16 & 2,66 \\
\hline
\end{tabular}

Indeks luas daun tumpangsari pada perlakuan jarak tanam jagung $120 \mathrm{~cm} \times 30 \mathrm{~cm}$ dan $60 \mathrm{~cm} \times 30 \mathrm{~cm}$ berbeda tidak nyata $(P>0,05)$. Indeks luas daun tumpangsari tertinggi terdapat pada perlakuan jarak tanam jagung $120 \mathrm{~cm}$ x $30 \mathrm{~cm}$, yaitu 2,36 dan terendah pada perlakuan jarak tanam jagung $90 \mathrm{~cm} \times$ $30 \mathrm{~cm}$. Perlakuan jarak tanam jagung $120 \mathrm{~cm}$ x $30 \mathrm{~cm}$ menghasilkan ILD tumpangsari tertinggi yaitu 2,36, artinya tanaman pada jarak tanaman tersebut mampu menyerap cahaya matahari lebih dari $90 \%$ dan tingginya ketersediaan cahaya untuk mendukung fotosintesis menyebabkan biomassa yang dihasilkan akan tinggi. Hal ini disebabkan oleh nilai indeks luas daun kacang hijau yang lebih tinggi pada jarak tanam jagung $120 \mathrm{~cm} \times 30 \mathrm{~cm}$ yaitu 1,76 dan indeks luas daun jagung terendah pada perlakuan jarak tanam jagung $120 \mathrm{~cm} \times 30 \mathrm{~cm}$, yaitu 0,59. Indeks luas daun tumpangsari terendah pada perlakuan jarak tanam $90 \mathrm{~cm} \times 30 \mathrm{~cm}$, yaitu 1,92 , artinya tanaman pada jarak tanam jagung $90 \mathrm{~cm} \times 30 \mathrm{~cm}$ dapat menyerap cahaya matahari lebih dari 50\%. Jarak tanam jagung $90 \mathrm{~cm} \mathrm{x}$ $30 \mathrm{~cm}$ menghasilkan nilai indeks luas daun yang rendah baik pada tanaman jagung maupun kacang hijau.

Tabel 2. Rata-rata indeks luas daun pada sistem tumpangsari

\begin{tabular}{c|c|c|c|c|c}
\hline \multirow{2}{*}{ Jarak Tanam Jagung $(\mathrm{cm})$} & \multicolumn{2}{c}{ Jagung } & \multicolumn{2}{c}{ Kacang Hijau } & ILD Tumpangsari \\
\cline { 2 - 5 } & $\operatorname{LD}\left(\mathrm{cm}^{2}\right)$ & $\operatorname{ID}(\mathrm{a})$ & $\operatorname{LD}\left(\mathrm{cm}^{2}\right)$ & $\operatorname{LD}(\mathrm{b})$ & $(\mathrm{a}+\mathrm{b})$ \\
\hline $60 \times 30$ & $1.676,43 \mathrm{~b}$ & $0,93 \mathrm{a}$ & $917,50 \mathrm{~b}$ & $1,27 \mathrm{~b}$ & $2,20 \mathrm{ab}$ \\
\hline $90 \times 30$ & $1.869,54 \mathrm{ab}$ & $0,69 \mathrm{~b}$ & $1026,48 \mathrm{~b}$ & $1,23 \mathrm{~b}$ & $1,92 \mathrm{~b}$ \\
\hline $120 \times 30$ & $2.149,50 \mathrm{a}$ & $0,59 \mathrm{~b}$ & $1429,79 \mathrm{a}$ & $1,76 \mathrm{a}$ & $2,36 \mathrm{a}$ \\
\hline
\end{tabular}

Keterangan : angka-angka yang diikuti oleh huruf yang sama berbeda tidak nyata pada DMRT 5\%

Luas daun jagung tertinggi diperoleh pada perlakuan jarak tanam jagung $120 \mathrm{~cm}$ x $30 \mathrm{~cm}$ dengan nilai $2.149,50 \mathrm{~cm}^{2}$. Hal ini disebabkan karena pada perlakuan jarak tanam jagung $120 \mathrm{~cm}$ x $30 \mathrm{~cm}$ kompetisi antar tanaman dalam mendapatkan cahaya matahari lebih rendah dibandingkan jarak tanam lainnya. Selain itu, luas daun yang tinggi maka proses fotosintesis berjalan dengan baik sehingga fotosintat yang dihasilkan akan tinggi. Tingginya luas daun yang dihasilkan berdampak pada tingginya bobot kering total tanaman. Sesuai dengan pernyataan Taufiqurrahman \&
Guritno (2018), bahwa nilai luas daun tanaman jagung semakin meningkat dengan bertambahnya jarak tanam. Indeks luas daun jagung tertinggi pada jarak tanam jagung $60 \mathrm{~cm} \times 30 \mathrm{~cm}$ dengan nilai 0,93. Jarak tanam jagung yang semakin rapat maka populasinya semakin banyak sehingga nilai indeks luas daun semakin tinggi. Pertambahan jumlah populasi tanaman mampu meningkatkan nilai indeks luas daun yang lebih tinggi (Neonbeni et al., 2019).

Luas daun kacang hijau tertinggi pada jarak tanam jagung $120 \mathrm{~cm} \times 30 \mathrm{~cm}$ dengan nilai $1429,79 \mathrm{~cm}^{2}$. Hal ini disebabkan karena pengaruh tajuk tanaman jagung yang tidak menutupi tajuk tanaman kacang hijau sehingga cahaya matahari yang diserap oleh tajuk tanaman kacang hijau lebih optimal dibandingkan jarak tanam lainnya. Indeks luas daun kacang hijau tertinggi diperoleh pada perlakuan jarak tanam jagung $120 \mathrm{~cm} \times 30 \mathrm{~cm}$. Hasil penelitian Wulandari \& Guritno (2018) menunjukkan bahwa indeks luas daun tanaman kacang tanah lebih tinggi pada jarak tanam tebu $25 \mathrm{~cm} \times 50 \mathrm{~cm}$ dibandingkan dengan jarak tanam $25 \mathrm{~cm} \times 25 \mathrm{~cm}$. Hal ini mengindikasikan bahwa semakin lebar jarak tanam maka tajuk tanaman tidak saling menutupi satu sama lain dalam mendapatkan cahaya matahari sehingga indeks luas daun menjadi lebih tinggi.

NKL bobot berangkasan tertinggi dihasilkan oleh perlakuan jarak tanam jagung $120 \mathrm{~cm} \times 30 \mathrm{~cm}$ yaitu 1,42 (Tabel 3). Capaian ini dipengaruhi oleh nilai ILD tumpangsari (Tabel 2). Semakin tinggi nilai ILD tumpangsari maka semakin tinggi pula nilai NKL bobot berangkasan. Selain itu, penyebab NKL bobot berangkasan tinggi pada jarak tanam jagung $120 \mathrm{~cm}$ x $30 \mathrm{~cm}$ adalah nilai relatif bobot berangkasan tanaman jagung dan tanaman kacang hijau yang tinggi. Bobot berangkasan per petak tanaman jagung diperoleh pada perlakuan jarak tanam jagung $60 \mathrm{~cm}$ x $30 \mathrm{~cm}$ lebih tinggi dari jarak tanam jagung yang lain. Hal ini disebabkan karena jarak tanam yang semakin rapat akan meningkatkan jumlah populasi tanaman, sehingga mempengaruhi bobot berangkasan/petak tanaman jagung. Sesuai dengan hasil penelitian Wangiyana et al. (2018), bahwa jarak tanam $60 \mathrm{~cm} \times 20 \mathrm{~cm}$ menghasilkan bobot berangkasan tanaman jagung ton/ha yang lebih tinggi dibandingkan dengan jarak tanam $75 \mathrm{~cm} \times 20 \mathrm{~cm}$ dan $90 \mathrm{~cm} \times 20 \mathrm{~cm}$. Jarak tanam yang semakin rapat akan meningkatkan populasi lebih banyak, sehingga mempengaruhi hasil produksi/hektar.

Bobot berangkasan/petak tanaman kacang hijau lebih tinggi pada jarak tanam jagung $120 \mathrm{~cm}$ x $30 \mathrm{~cm}$ dibandingkan kedua jarak tanam yang lebih kecil. Hal ini karena pada jarak tanam yang lebih lebar populasi tanaman jagung menjadi lebih sedikit sehingga tingkat kompetisi antara tanaman kacang hijau dan jagung dalam menyerap cahaya matahari, air, dan unsur hara menjadi relatif kecil. 
Tabel 3. Rata-rata NKL bobot berangkasan

\begin{tabular}{|c|c|c|c|c|c|c|c|}
\hline \multirow[b]{2}{*}{$\begin{array}{c}\text { Jarak Tanam } \\
\text { Jagung }\end{array}$} & \multicolumn{3}{|c|}{ Jagung } & \multicolumn{3}{|c|}{ Kacang Hijau } & \multirow[b]{2}{*}{$\begin{array}{c}\text { NKL Bobot } \\
\text { Berangkasan } \\
(\mathrm{a}+\mathrm{b})\end{array}$} \\
\hline & $\begin{array}{l}\text { BBP } \\
(\mathrm{kg})\end{array}$ & $\begin{array}{c}\text { Mono } \\
\text { kultur } \\
(\mathrm{kg}) \\
\end{array}$ & RBB (a) & $\begin{array}{l}\text { BBP } \\
(\mathrm{kg})\end{array}$ & $\begin{array}{l}\text { Mono } \\
\text { kultur } \\
(\mathrm{kg})\end{array}$ & $\mathrm{RBB}(\mathrm{b})$ & \\
\hline $60 \times 30$ & $5,79 \mathrm{a}$ & 8,4 & $0,68 \mathrm{ab}$ & $0,34 \mathrm{~b}$ & \multirow{3}{*}{0,725} & $0,47 \mathrm{~b}$ & $1,15 \mathrm{~b}$ \\
\hline $90 \times 30$ & $3,66 \mathrm{~b}$ & 6,37 & $0,57 \mathrm{~b}$ & $0,37 \mathrm{~b}$ & & $0,51 \mathrm{~b}$ & $1,08 \mathrm{~b}$ \\
\hline $120 \times 30$ & $3,57 \mathrm{~b}$ & 4,69 & $0,76 \mathrm{~b}$ & $0,48 \mathrm{a}$ & & $0,66 \mathrm{a}$ & $1,42 \mathrm{a}$ \\
\hline
\end{tabular}

NKL bobot biji tertinggi dihasilkan oleh varietas Vima-3 dan berbeda tidak nyata dengan varietas Vima-2 (Tabel 4). Hal ini disebabkan karena nilai relatif bobot biji kacang hijau Vima-2 dan Vima-3 lebih tinggi dari nilai relatif bobot biji jagung. Pada relatif bobot biji varietas yang sama Vima-3 lebih tinggi dari varietas Vima-1, Vima-2, dan Kutilang. Hasil ini juga didukung oleh komponen hasil yaitu jumlah polong dan bobot biji/tanaman kecuali bobot 100 biji. Perlu diketahui bahwa karakteristik genetik varietas kacang hijau yang mudah beradaptasi sesuai dengan deskripsi Balai Penelitian Tanaman Aneka Kacang \& Umbi. Hasil rata-rata varietas kacang hijau Vima-1, Vima-2, Vima-3, dan Kutilang secara berturut-turut, yaitu 1,38 ton/ha, 1,8 ton/ha, 1,8 ton/ha, dan 1,13 ton/ha (Balitkabi, 2016).

Bobot biji/petak jagung lebih tinggi pada jarak tanam jagung $60 \mathrm{~cm}$ × $30 \mathrm{~cm}$ dan $90 \mathrm{~cm} \times 30 \mathrm{~cm}$ dibandingkan dengan pada jarak tanam $120 \mathrm{~cm}$ x $30 \mathrm{~cm}$. Hal ini disebabkan karena jumlah populasi tanaman yang lebih banyak sehingga mampu meningkatkan produksi tanaman. Muyassir (2012) menyatakan bahwa peningkatan kerapatan tanaman/satuan luas dapat meningkatkan jumlah populasi tanaman/satuan luas, sehingga mampu meningkatkan produksi tanaman. Bobot biji jagung relatif lebih tinggi pada jarak tanam jagung $90 \mathrm{~cm} x$ $30 \mathrm{~cm}$. Hal ini disebabkan karena hasil/petak pada pola tanam monokultur jagung lebih rendah dibandingkan jarak tanam jagung $60 \mathrm{~cm} \times 30 \mathrm{~cm}$ dan $120 \mathrm{~cm} \times 30 \mathrm{~cm}$. Hasil pembagian bobot pipilan/petak tumpangsari dengan bobot pipilan/ petak monokultur pada jarak tanam jagung $90 \mathrm{~cm} \times 30 \mathrm{~cm}$ menjadi lebih tinggi.

Bobot biji/petak dan bobot biji kacang hijau lebih tinggi pada jarak tanam jagung $120 \mathrm{~cm} \times 30 \mathrm{~cm}$ (Tabel 5). Jarak tanam jagung yang semakin lebar membuat tingkat kompetisi antar tanaman jagung dengan kacang hijau dalam mendapatkan sinar matahari, unsur hara, dan air menjadi lebih rendah. Menurut Aisyah \& Herlina (2018), bahwa semakin rapat jarak tanam jagung maka cahaya matahari yang diterima oleh tanaman kacang-kacangan akan berkurang. Hal ini menyebabkan aktivitas fotosintesis akan terhambat yang berakibat pada produksi tanaman akan semakin menurun. Hasil penelitian pada tanaman padi juga menunjukkan perilaku yang sama yaitu hasil gabah/ rumpun cenderung menurun seiring dengan peningkatan kepadatan populasi tanaman (Sumardi, 2010).

Tabel 4. Rata-rata NKL bobot biji pada masing-masing varietas kacang hijau

\begin{tabular}{|c|c|c|c|c|c|c|c|}
\hline \multirow[b]{2}{*}{$\begin{array}{c}\text { Varietas } \\
\text { Kacang Hijau }\end{array}$} & \multicolumn{3}{|c|}{ Jagung } & \multicolumn{3}{|c|}{ Kacang Hijau } & \multirow{2}{*}{$\begin{array}{c}\text { NKL } \\
\text { Bobot Biji } \\
(a+b)\end{array}$} \\
\hline & $\begin{array}{c}\text { Bobot Pipilan } \\
\text { /Petak (kg) }\end{array}$ & $\begin{array}{c}\text { Mono } \\
\text { kultur } \\
(\mathrm{kg})\end{array}$ & $\begin{array}{c}\text { Relatif } \\
\text { Bobot } \\
\text { Pipilan (a) }\end{array}$ & $\begin{array}{c}\text { Bobot Biji } \\
\text { Petak } \\
(\mathrm{kg})\end{array}$ & $\begin{array}{c}\text { Mono } \\
\text { kultur } \\
(\mathrm{kg})\end{array}$ & $\begin{array}{c}\text { Relatif } \\
\text { Bobot Biji } \\
\text { (b) }\end{array}$ & \\
\hline Vima-1 & 6,19 & \multirow{4}{*}{9,44} & 0,65 & $0,55 \mathrm{bc}$ & 0,87 & $0,64 \mathrm{~b}$ & $1,29 \mathrm{~b}$ \\
\hline Vima-2 & 6,35 & & 0,67 & $0,61 \mathrm{ab}$ & 0,86 & $0,72 \mathrm{~b}$ & $1,39 \mathrm{ab}$ \\
\hline Vima-3 & 5,93 & & 0,64 & $0,67 \mathrm{a}$ & 0,74 & $0,92 \mathrm{a}$ & $1,56 \mathrm{a}$ \\
\hline Kutilang & 5,81 & & 0,61 & $0,52 \mathrm{c}$ & 0,79 & $0,68 \mathrm{~b}$ & $1,28 \mathrm{~b}$ \\
\hline
\end{tabular}


LESTARI et al.

Tabel 5. Rata-rata NKL bobot biji pada masing-masing jarak tanam jagung

\begin{tabular}{|c|c|c|c|c|c|c|c|}
\hline \multirow[b]{2}{*}{$\begin{array}{l}\text { Jarak tanam } \\
\text { jagung }(\mathrm{cm})\end{array}$} & \multicolumn{3}{|c|}{ Jagung } & \multicolumn{3}{|c|}{ Kacang hijau } & \multirow[b]{2}{*}{$\begin{array}{c}\text { NKL Bobot Biji } \\
(a+b)\end{array}$} \\
\hline & $\begin{array}{c}\text { Bobot Pipilan } \\
\text { Petak (kg) }\end{array}$ & $\begin{array}{c}\text { Monokultur } \\
(\mathrm{kg})\end{array}$ & $\begin{array}{l}\text { Relatif Bobot } \\
\text { Pipilan (a) }\end{array}$ & $\begin{array}{c}\text { Bobot Biji } \\
\text { /Petak (kg) }\end{array}$ & $\begin{array}{c}\text { Monokultur } \\
(\mathrm{kg})\end{array}$ & $\begin{array}{c}\text { Relatif } \\
\text { Bobot Biji }\end{array}$ & \\
\hline $60 \times 30$ & $7,75 \mathrm{a}$ & 11,35 & $0,69 \mathrm{a}$ & $0,51 \mathrm{~b}$ & \multirow{3}{*}{0,81} & $0,63 \mathrm{~b}$ & 1,33 \\
\hline $90 \times 30$ & $6,24 \mathrm{a}$ & 7,7 & $0,82 \mathrm{a}$ & $0,55 \mathrm{~b}$ & & $0,69 \mathrm{~b}$ & 1,51 \\
\hline $120 \times 30$ & $4,22 \mathrm{~b}$ & 9,28 & $0,42 \mathrm{~b}$ & $0,71 \mathrm{a}$ & & $0,89 \mathrm{a}$ & 1,31 \\
\hline \multicolumn{8}{|c|}{ Keterangan : angka-angka yang diikuti oleh huruf yang sama pada kolom yang sama berbeda tidak nyata pada } \\
\hline & & & & & & & \\
\hline
\end{tabular}

Perlakuan jarak tanam jagung berpengaruh tidak nyata terhadap NKL bobot biji (Tabel 5). Jarak tanam jagung yang rapat menyebabkan jumlah populasi tanaman/ petak semakin banyak, namun menurunkan hasil/ tanaman jagung. Hal ini didukung oleh bobot pipilan/ tanaman dan bobot 100 biji yang menunjukkan semakin lebar jarak tanam maka semakin tinggi hasilnya. Terjadinya persaingan yang tinggi antar tanaman, sehingga hasil tongkol jagung menjadi rendah. Pada jarak tanam jagung yang lebar menyebabkan jumlah populasi tanaman/petak semakin sedikit, namun meningkatkan bobot pipilan/tanaman tanaman jagung. Hal ini disebabkan karena tingkat persaingan yang rendah antar tanaman sehingga hasil tongkol jagung menjadi tinggi.

Sistem tanam tumpangsari menghasilkan bobot biji jagung/petak lebih rendah dibandingkan dengan bobot biji jagung/petak pada monokultur dengan jarak tanam yang sama. Hal ini disebabkan karena jumlah populasi tanaman jagung pada monokultur 2 kali lebih banyak daripada sistem tumpangsari. Selain itu, bobot biji/petak kacang hijau tumpangsari lebih rendah dibandingkan hasil/ petak kacang hijau pada monokultur. Hal ini disebabkan karena jumlah populasi tanaman kacang hijau pada monokultur 2 kali lebih banyak daripada sistem tumpangsari. Hasil penelitian Lingga et al. (2015) menunjukkan bahwa hasil kacang hijau dan jagung/ satuan luas pada monokultur lebih tinggi dari tumpangsari. Jumlah populasi pada monokultur 2 kali lebih banyak dari tumpangsari disebabkan karena pada monokultur terdapat 1 jenis tanaman, sedangkan pada tumpangsari terdapat 2 jenis tanaman yang berbeda, sehingga untuk menyetarakan lahan dengan sistem tumpangsari maka pada monokultur ditanam 2 kali lebih banyak. Sesuai dengan Beets (1982), bahwa untuk menyetarakan lahan antara tumpangsari dengan monokultur dilakukan penanaman 2 kali lipat pada monokultur agar interaksi antar tanaman baik ditumpangsari maupun monokultur menjadi seimbang.

Tanaman kacang hijau tidak cocok ditumpangsarikan dengan tanaman jagung pada musim penghujan. Curah hujan rata-rata 315-614 mm/bulan sesuai untuk tanaman jagung tetapi tidak sesuai untuk tanaman kacang hijau yang menghendaki curah hujan rata-rata 50$200 \mathrm{~mm} /$ bulan (Humaedah, 2014).

\section{KESIMPULAN}

Secara umum tumpangsari jagung dan kacang hijau mempunyai NKL $>1$, yang berarti efisien secara ekologi dan agronomi. Tingkat efisien tersebut dapat dibedakan berdasarkan jarak tanam jagung dan varietas kacang hijau. Efisiensi secara ekologi yang terbaik diperoleh pada jarak tanam jagung $120 \mathrm{~cm}$ x $30 \mathrm{~cm}$, sedangkan efisiensi secara agronomi yang terbaik diperoleh pada varietas kacang hijau Vima-3.

\section{DAFTAR PUSTAKA}

Aisyah, Y. \& Herlina, N. (2018). Pengaruh jarak tanam tanaman jagung manis (Zea mays L. var. saccharata) pada tumpangsari dengan tiga varietas tanaman kedelai (Glycine max (L.) Merrill). Jurnal Produksi Tanaman, 6(1), 66-75.

Aminah, I.S., Rosmiah,R. \& Yahya, M.H. (2014). Efisiensi pemanfaatan lahan pada tumpangsari jagung (Zea mays L.) dan kedelai (Glycine max L. Merrill) di lahan pasang surut. Jurnal Lahan Suboptimal, 3(1), 62-70. DOI: .https:// doi.org/10.33230/JLSO.3.1.2014.107

Balai Penelitian Tanaman Aneka Kacang \& Umbi. (2016). Deskripsi Tanaman Kacang Hijau Varietas Kutilang, Vima 1, Vima 2, Vima 3. Agro Inovasi, Malang.

Beets, W.C. (1982). Multiple Cropping and Tropical Farming Systems. Gower Publishing Co.

Catharina, T. S. (2009). Respon tanaman jagung pada sistem monokultur dengan tumpangsari kacang-kacangan terhadap ketersediaan unsur hara $\mathrm{N}$ dan nilai kesetaraan lahan di lahan kering. Ganec Swara Edisi Khusus, 3(3), 17-21.

Damanhuri, D., DU, R.M.M. \& Setyohadi, D.P.S. (2017). Pengembangan diversifikasi usaha tani sebagai penguatan ekonomi di Kabupaten Bojonegoro, Tulungagung. Jurnal Cakrawala, 11(1), 33-47. DOI: https://doi.org/10.32781/ cakrawala.v11i1.4. 
Dewanto, F.G., Londok, J.J., Tuturoong, R.A. \& Kaunang, W.B. (2013). Pengaruh pemupukan anorganik dan organik terhadap produksi tanaman jagung sebagai sumber pakan. Jurnal Zootec, 32(5), 1-8. DOI: https://doi.org/10.35792/ zot.32.5.2013.982

Dewi, T. N., Sebayang, H.T. \& Suminarti, N.E. (2018). Upaya efisiensi pemanfaatan lahan melalui sistem tanam tumpangsari sorgum dengan kacangkacangan di lahan kering. Jurnal Produksi Tanaman, 5(8), 1356-1366.

Gomez, K.A. \& Gomez, A.A. (1984). Statistical Procedures for Agricultural Research. John Wiley $\&$ Sons., New York.

Humaedah, U. (2014). Syarat Tumbuh dan Budidaya Kacang Hijau..http://cybex.deptan.go.id/ penyuluhan/syarattumbuhdanbudidayakacang -hijau. 10 Maret, 2019.

Kamilah, A.\& Yulianah, Y. (2016). Land tenure system dalam melindungi lahan pertanian pangan berkelanjutan dan kedudukannya dalam hukum agraria nasional. Jurnal Hukum Mimbar Justitia, 2(2), 785-805. DOI: https://doi.org/ 10.35194/jhmj.v2i2.31

Karima, S.S., Nawawi, M. \& Herlina, N. (2013). Pengaruh saat tanam jagung dalam tumpangsari tanaman jagung (Zea mays L.) dan brokoli (Brassica oleracea L. var. botrytis). Jurnal Produksi Tanaman, 1(3), 87-92.

Lingga, G. K., Purwanti, S. \& Toekidjo. (2015). Hasil dan kualitas benih kacang hijau (Vignaradiata(L.)Wilczek) tumpangsari barisan dengan jagung manis (Zea mays kelompok Saccharata). Jurnal Vegetalika, 4(2), 39-47. DOI: https://doi.org/10.22146/veg.9273.

Manyamsari, I. \& Mujiburrahmad, M. (2014). Karakteristik petani dan hubungannya dengan kompetensi petani lahan sempit (kasus: di desa Sinar Sari kecamatan Dramaga kabupaten Bogor Jawa Barat). Jurnal Agrisep, 15(2), 5874.

Muyassir. (2012). Efek jarak tanam, umur dan jumlah bibit terhadap hasil padi sawah (Oryza sativa L.). Jurnal Manajemen Sumberdaya Lahan, 1(2), 207-212.

Neonbeni, E.Y., Agung, I.G.A.M.S. \& Suarna, I.M. (2019). Pengaruh populasi tanaman terhadap pertumbuhan dan hasil beberapa varietas jagung (Zea mays L.) lokal di lahan kering. Savana Cendana, 4(01),9-11.DOI: https://doi.org/10. 32938/sc.v4i01.298.

Primiani, C.N. \& Pujiati, P. (2017). Leguminoceae kacang gude (Cajanus cajan) dan manfaatnya untuk kesehatan. Prosiding Seminar Nasional Hasil Penelitian.LPPM Universitas PGRI Madiun: 31-35.
Purnama, J. M. \& Tohari, D.K. (2013). Kajian teknologi parit berbahan organik pada produktivitas tumpangsari jagung (Zea mays L.) dengan kacang hijau (Vigna radiata (L.) Wilczek di lahan kering. Jurnal Vegetalika, 2(2), 40-49. DOI: https://doi.org/10.22146/veg.2414.

Putra, J. P. Wicaksono, H.K.P. \& Herlina, N. (2017). Studi sistem tumpangsari jagung (Zea mays L.) dan bawang prei (Allium porrum L.) pada berbagai jarak tanam. Jurnal Produksi Tanaman, 5(5), 748755.

Rosmaiti, R. (2018). Pertumbuhan dan produksi tanaman kacang hijau (Vigna radiata, L) pada berbagai sistem olah tanah di lahan sawah tadah hujan. Jurnal Penelitian Agrosamudra, 5(2), 39-45.

Sabaruddin, L., Hasid, R., Muhidin \& Anas, A.A. (2011). Pertumbuhan, produksi dan efisiensi pemanfaatan lahan dalam sistem tumpangsari jagung dan kacang hijau dengan interval penyiraman berbeda. Jurnal Agronomi Indonesia (Indonesian Journal of Agronomy), 39(3), 153-159. DOI: https://doi.org/10.24831/jai.v39i3.14958.

Sinaga, A.S., Guritno, B. \& Sudiarso, S. (2017). Pengaruh dosis kompos sampah rumah tangga terhadap pertumbuhan dan hasil tiga varietas buncis tipe tegak (Phaseolus vulgaris L.). Jurnal Produksi Tanaman, 5(6), 949-950.

Sumardi, (2010). Produktivitas padi sawah pada kepadatan populasi berbeda. Jurnal Ilmu-Ilmu Pertanian Indonesia, 12(1), 49-54. DOI: https:// doi.org/10.31186/jipi.12.1.49-54.

Susilo, D. E. H. (2015). Identifikasi nilai konstanta bentuk daun untuk pengukuran luas daun metode panjang kali lebar pada tanaman hortikultura di tanah gambut. Anterior Jurnal, 14(2), 139-146. DOI: https://doi.org/10.33084/anterior.v14i2. 178.

Taufiqurrahman, M. \& Guritno, B. (2018). Pengaruh jarak tanam dan galur harapan terhadap pertumbuhan dan produksi benih jagung hibrida (Zea mays L.). Jurnal Produksi Tanaman, 6(6), 1020 $-1027$.

Turmudi, E. (2002). Kajian pertumbuhan dan hasil dalam sistem tumpangsari jagung dengan empat kultivar kedelai pada berbagai waktu tanam. Jurnal Ilmu-Ilmu Pertanian Indonesia, 4(2), 8996.

Utomo, W., Astiningrum, M. \& Susilowati, Y.E. (2017). Pengaruh mikoriza dan jarak tanam terhadap hasil tanaman jagung manis (Zea mays Var. Saccharata Sturt). Jurnal Ilmu Pertanian Tropi$k a$ dan Subtropika (Journal of Tropical and Subtropical Agricultural Science, 2(1), 28-33.

Wahyuni, P., Barunawati, N. \& Islami, T. (2017). Respon pertumbuhan dan hasil jagung manis (Zea mays L. Saccharata) dalam sistem tumpangsari dengan 


\section{LESTARI et al.}

kacang hijau (Vigna radiata L.). Jurnal Produksi Wulandari, P. \& Guritno, B. (2019). Pengaruh jarak tanam Tanaman, 5(8), 1308-1315.

Wangiyana, W., Gunartha, I.G.E. \& Farida, N. (2018). Respon beberapa varietas jagung pada jarak tanam berbeda terhadap penyisipan beberapa baris kacang tanah. Crop Agro, Scientific Journal of Agronomy, 11 dan jumlah tanaman per lubang pada pertumbuhan dan hasil kacang tanah (Arachis hipogaea L.) sebagai tanaman sela di lahan tebu (Saccharum officinarum (2), 104-112. L.). Jurnal Produksi Tanaman, 6(7), 1513-1520. 